\title{
Protein Intake in Early Infancy: Effects on Plasma Amino Acid Concentrations, Insulin Metabolism, and Growth
}

\author{
IRENE E. M. AXELSSON, STEN A. IVARSSON, AND NIELS C. R. RÄIHÄ \\ Department of Pediatrics, University of Lund, Malmö General Hospital, Malmö, Sweden
}

\begin{abstract}
The effects of different protein intakes on wt gain, insulin secretion, and plasma concentrations of amino acids have been evaluated in a prospective study involving 30 normal term infants. The infants were studied from 4.0 to 6.0 mo of age. Ten infants were breast-fed (BF), the others were randomly divided into two groups of 10 infants. One group was fed a formula containing $1.3 \mathrm{~g}$ protein $/ 100$ $\mathrm{mL}(\mathrm{F} \mathrm{1.3})$, the other a formula with $1.8 \mathrm{~g}$ protein $/ 100 \mathrm{~mL}$ (F 1.8). The formulas were isocaloric $(72 \mathrm{kcal} / 100 \mathrm{~mL})$, and the fat concentrations were $3.5 \mathrm{~g} / 100 \mathrm{~mL}$ (F 1.3) and $3.2 \mathrm{~g} / 100 \mathrm{~mL}$ (F 1.8). All infants received the same supplementary foods. The urinary $C$-peptide excretion in the infants fed the $F$ 1.8-formula was $4.4 \pm 2.1 \mathrm{nmol} / \mathrm{mmol}$ creatinine or $19.4 \pm 12.9 \mathrm{nmol} / \mathrm{m}^{2}$, significantly higher than that in the infants fed the $F$ 1.3-formula $(2.6 \pm 1.5$ and $7.9 \pm 5.1$ ) or the BF infants $(1.7 \pm 1.4$ and $6.3 \pm 6.0)$. Gain in wt was $18.0 \pm 4.3,19.9 \pm 3.9,22.8 \pm 1.6 \mathrm{~g} / \mathrm{kg} / \mathrm{wk}$ and corresponded to protein intakes of $1.3 \pm 0.2,1.9 \pm$ 0.3 , and $2.6 \pm 0.2 \mathrm{~g} / \mathrm{kg} / \mathrm{d}$, in the BF, F 1.3, and F 1.8 groups, respectively. Gain in length was $6.7 \pm 1.8$ (BFgroup), $6.2 \pm 2.5$ (F 1.3-group), and $7.6 \pm 2.2$ (F 1.8group) $\mathrm{mm} / \mathrm{m} / \mathrm{wk}$. Wt gain correlated with urinary $\mathrm{C}$ peptide excretion at $6.0 \mathrm{mo}(r=0.51, p<0.01)$ and with protein intake $(r=0.43, p<0.01)$. Furthermore, protein intake correlated with urinary $C$-peptide excretion $(r=$ $0.66, p<0.001$ ). Caloric intake from carbohydrate and fat correlated both with wt gain $(r=0.34, p<0.05)$ and with urinary $C$-peptide $(r=0.44, p<0.05)$. A higher protein intake during a meal resulted in a higher postprandial excretion of urinary $C$-peptide. The difference between plasma $C$-peptide ( $\Delta C$-peptide) before and after a meal was highest in the groups of infants fed the F 1.8-formula. The intakes of the insulin-releasing amino acids (arginine, lysine, leucine, phenylalanine, valine, isoleucine, and threonine) were higher in the F 1.8-group than in the F 1.3and $B F$-groups. The sums of the fasting plasma concentrations of these amino acids were 64.8 (BF), 83.6 (F 1.3), and 96.3 (F 1.8) $\mu \mathrm{mol} / 100 \mathrm{~mL}$. The plasma concentrations of the branched-chain amino acids, valine, leucine, and isoleucine correlated with wt gain and plasma valine-glycine ratio increased with higher protein intake. These results suggest that protein amino acid-induced insulin secretion could be a factor promoting growth in infants on high protein intakes. (Pediatr Res 26: 614-617, 1989)
\end{abstract}

\section{Abbreviations}

BF, breast-fed

F 1.3, formula with $1.3 \mathrm{~g}$ protein/100 $\mathrm{mL}$

Received April 17, 1989; accepted July 21, 1989.

Correspondence Irene E. M. Axelsson, Department of Pediatrics, University of Lund, Mälmo General Hospital, S-21401 Mālmo, Sweden.
F 1.8, formula with $1.8 \mathrm{~g}$ protein $/ 100 \mathrm{~mL}$

Several studies have demonstrated a higher growth rate after 3 mo of age in artificially fed infants than in BF infants (1-4). It is not known with certainty whether breast milk alone is inadequate to meet the infants' growth potential after 3 mo of age or whether artificially fed infants have an accelerated growth velocity. At 9 mo, exclusively BF infants seem to be at risk of iron deficiency (5). However, when complementary feeding is introduced at 4 to $6 \mathrm{mo}$ of age in BF infants, there seem to be no signs of nutritional deficiencies $(6,7)$. Normal concentrations of plasma proteins have recently been found at $6 \mathrm{mo}$ in BF infants receiving complementary foods (3). This would suggest that these infants are not commonly protein deficient.

Artificially fed infants have higher protein intakes and higher concentrations of many plasma amino acids from 4 to 6 mo of age than BF infants (8). Certain amino acids stimulate insulin secretion (9-11), and normal term infants fed cow's milk formula have higher levels of plasma insulin and urinary C-peptide than infants fed breast milk $(12,13)$.

Insulin has been proposed as a growth-promoting factor during the fetal period (14). Also children with insulin deficiency are retarded in growth (14-16).

In the present investigation we have studied the relationship between protein intake, growth, and insulin secretion in term infants. Furthermore, we have evaluated the effects of different protein and amino acid intakes on plasma concentrations of the insulin-releasing amino acids.

\section{MATERIALS AND METHODS}

This is a prospective study of 30 healthy infants born in Malmö, Sweden. The infants were recruited from local Child Health Centers at 3 mo of age. From 3.0 to 4.0 mo of age, 20 artificially fed infants received conventional standard formulas, containing between 1.3 and $1.8 \mathrm{~g} / 100 \mathrm{~mL}$ of protein and between 68 and $73 \mathrm{kcal} / 100 \mathrm{~mL}$ of energy. Ten other infants were exclusively BF before entering the study. The infants participated in the study from 4.0 to 6.0 mo of age. The inclusion criteria were: I) term single birth after uncomplicated pregnancy and delivery, 2) appropriate wt for gestational age, 3) normal wt gain [according to the Swedish growth charts (17)] from birth to the age of $4.0 \mathrm{mo}, 4)$ no obvious disease or malformation, 5) parental informed consent to a blind trial in the artificially fed infants.

Feeding regimens. At 4 mo of age 20 infants were randomly assigned either to a formula with a low protein content of $1.3 \mathrm{~g}$ / $100 \mathrm{~mL}$ (F 1.3, $9 / \delta 6 / 4)$ or to one with a high protein content of $1.8 \mathrm{~g} / 100 \mathrm{~mL}$ (F $1.8,9 / \% 6 / 4)$. Both formulas were isocaloric (72 $\mathrm{kcal} / 100 \mathrm{~mL}$ ), with a carbohydrate content of $8.3 \mathrm{~g} / 100 \mathrm{~mL}$ and a whey to casein ratio of $50 / 50$. The fat content was $3.5 \mathrm{~g} / 100$ 
$\mathrm{mL}$ in $\mathrm{F} 1.3$ and $3.2 \mathrm{~g} / 100 \mathrm{~mL}$ in $\mathrm{F} 1.8$. The formulas, manufactured specially for this study by AB Findus, Bjuv, Sweden, were labeled with code numbers without identification of protein content. Ten BF infants were used as controls (BF, $\$ / \% 3 / 7$ ). Commercial fruit and vegetable purées were given from $4.0 \mathrm{mo}$ and meat and fish preparations from 5.0 mo, according to the general customs in the country. The parents were instructed to carefully record the volume of the formula intakes in $\mathrm{mL}$ and the amounts of supplementary foods in teaspoons at every meal during the whole study period. At each visit these records were checked by I.A. together with the parents. The volumes of breast milk consumed over a 48 -h period were determined by weighing the infant before and after each feeding at 4.0 and 6.0 mo of age on an automatic electronic balance (Umedico, Rosersberg, Sweden, precision $\pm 1 \mathrm{~g}$ ). Protein and energy intakes from human milk were calculated on the basis of $0.96 \mathrm{~g}$ protein $/ 100 \mathrm{~mL}$ and $65 \mathrm{kcal} / 100 \mathrm{~mL}$ (18). The contents of protein, carbohydrate, fat, and total energy in the formulas and supplementary foods were given by the manufacturer. The protein content in the formulas was based on the total nitrogen content, quantified with the Kjeldahl method. To convert nitrogen to protein the factor 6.38 was used (19). Amino acids in the formulas were assayed with column chromatography, modified from Spackman et al. (20), and tryptophan with high-pressure liquid chromatography (21). Amino acid concentrations in human milk were taken from Rassin et al. (22). Daily protein, amino acid, and energy intakes were calculated from the feeding protocols and expressed on the basis of the infant's wt at $4.0 \mathrm{mo}$.

Growth measurements. Body wt, length, and head circumference were measured in the hospital at $4.0,4.5,5.0$, and $6.0 \mathrm{mo}$. The infants were weighed naked on a balance accurate to $\pm 1 \mathrm{~g}$. Crown-heel length was measured with a Lithell measuring board. A nurse or mother held the infant's head in contact with the fixed board and I.A. straightened the legs. Wt gain was calculated between 4.0 and $5.0,5.0$ and 6.0 , and 4.0 and $6.0 \mathrm{mo}$. Wt gain was expressed as $\mathrm{g} / \mathrm{kg} / \mathrm{wk}$ (based on the infant's wt at $4.0 \mathrm{mo}$ ). The length growth was calculated between 4.0 and $6.0 \mathrm{mo}$ and expressed as $\mathrm{mm} / \mathrm{m} / \mathrm{wk}$ (based on length at $4.0 \mathrm{mo}$ ).

Chemical methods. Urine was collected for $8 \mathrm{~h}$ at 4.0 and 6.0 mo. Blood samples were drawn at 4.0 and $6.0 \mathrm{mo}$, preprandially at approximately $1000 \mathrm{~h}$ and then 60 min after the feeding. Plasma and urine were stored at $-20^{\circ} \mathrm{C}$ until analyzed (within 2 mo for C-peptide). C-peptide in plasma and urine were measured as previously reported (23). The following method was used to analyze amino acids in plasma: after thawing the samples, $50 \mu \mathrm{L}$ of a loading buffer (containing $250 \mu \mathrm{M} 2$-ethyl-amino cystine as an internal standard) was added to $50 \mu \mathrm{L}$ of the sample, and then $50 \mu \mathrm{L}$ of $12 \%$ sulfosalicyclic acid for deproteinisation. After $60 \mathrm{~min}$ at $4^{\circ} \mathrm{C}, 50 \mu \mathrm{L}$ of $0.5 \mathrm{M} \mathrm{LiOH}$ were added to the tube to adjust the $\mathrm{pH}$ to 2.2 . The contents of the tube were mixed and centrifuged at $10000 \mathrm{rpm}$ for $10 \mathrm{~min}$. The supernatant was filtered through a $20 \mu \mathrm{m}$ Bio-Rad filter before analysis on an LKB amino analyzer (LKB 4151 Alpha-Plus) (24). The detection reagent used was ninhydrin; the amount of light absorbed was measured at $570 \mathrm{~nm}$. Data are presented at $\mu \mathrm{mol} / 100 \mathrm{~mL}$ plasma.

Statistics. F test of the equality of two variances was performed before the significance of the differences between groups were tested using Student's $t$ test. Linear regression, multiple linear regression, Spearman's Rank order correlation coefficient $(r)$, and Pearson's correlation coefficient were used for statistical analysis. The study protocol was approved by the Ethical Committee of the University of Lund.

\section{RESULTS}

A higher protein intake was associated with faster wt gain (Table 1). Daily protein intake correlated with weekly wt gain over the whole study period (Fig. 1). There were no significant differences in energy intakes from carbohydrate and fat between the two formula groups (Table 1 ).

Uninary excretion of C-peptide was higher in the infants fed the F 1.8-formula than in those fed the F 1.3-formula or breast milk (Table 2). Also, urinary C-peptide at 6.0 mo correlated with weekly wt gain from 5.0 to 6.0 mo (Figs. 1 and 2). Daily protein intake from 5.0 to $6.0 \mathrm{mo}$ and energy intake from carbohydrate and fat correlated with urinary C-peptide at $6.0 \mathrm{mo}$ (Fig. 1). Daily energy intake from carbohydrate and fat correlated with wt gain during the whole study period (Fig. 1). To evaluate, whether the protein-related increase in wt gain was mediated by increased insulin secretion, multiple linear regression analysis was performed. This gave the equation: wt gain $=5.05 \pm 0.23 \times$ U-C-peptide $+0.18 \times$ energy intake (carbohydrate and fat) $1.9 \times$ protein intake $\left(R^{2}=38 \%\right)$. If protein intake is excluded from the equation, wt gain $=5.37+0.18 \times U$-C-peptide +0.13 $\times$ energy intake $\left(R^{2}=36 \%\right)$.

Protein intake in a meal correlated with 8 -h postprandial

Table 1. Gain in wt and length and intake of protein and energy (mean $\pm S D$ from $4106 \mathrm{mo}$ )

\begin{tabular}{|c|c|c|c|c|}
\hline Group & $\begin{array}{c}\text { Wt gain } \\
(\mathrm{g} / \mathrm{kg} / \mathrm{wk})\end{array}$ & $\begin{array}{c}\text { Length gain } \\
(\mathrm{mm} / \mathrm{m} / \\
\text { wk) }\end{array}$ & $\begin{array}{l}\text { Protein } \\
\text { intake } \\
\text { (g/kg/day) }\end{array}$ & $\begin{array}{l}\text { Energy intake } \\
\text { from } \\
\text { carbohydrate } \\
\text { and fat } \\
(\mathrm{kcal} / \mathrm{kg} / \mathrm{d})\end{array}$ \\
\hline BF & $18.0 \pm 4.3$ & $6.7 \pm 1.8$ & $1.3 \pm 0.2$ & $74.9 \pm 10.8$ \\
\hline F 1.3 & $19.9 \pm 3.9$ & $6.2 \pm 2.5$ & $1.9 \pm 0.3^{*}$ & $90.1 \pm 12.7 \dagger$ \\
\hline F 1.8 & $22.8 \pm 1.6 t \neq$ & $7.6 \pm 2.2$ & $2.6 \pm 0.2^{*} \S$ & $94.4 \pm 8.8^{*}$ \\
\hline
\end{tabular}

${ }^{*} p<0.001$ when BF-group was compared to $\mathrm{F} 1.3$ or $\mathrm{F} 1.8$.

$\dagger p<0.01$ when BF-group was compared to $F 1.3$ or $F 1.8$.

$\$ p<0.05$ when $\mathrm{F}$ l.3-group was compared to $\mathrm{F} \mathrm{l} .8$.

$\S p<0.001$ when $F \quad 1.3$-group was compared to F 1.8 Student's $t$-test.

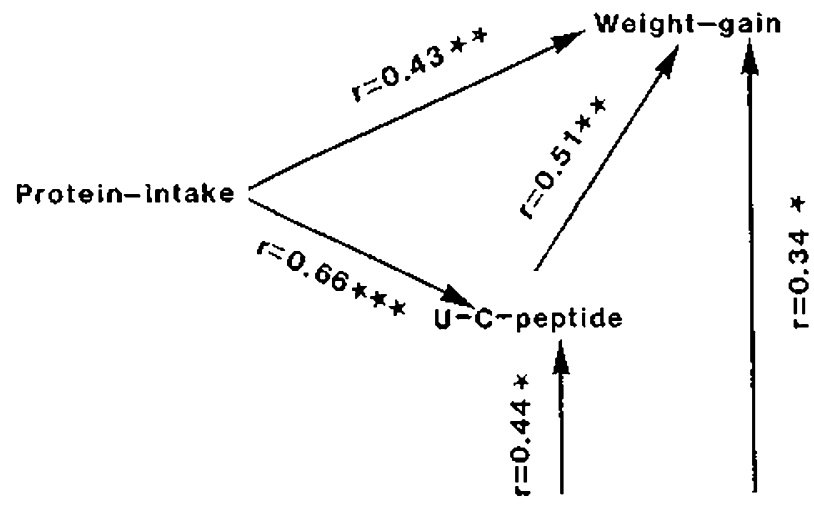

Calories from carbohydrate and fat

Fig. 1. Correlation coefficients between protein intake, caloric intake, urinary C-peptide excretion, and wt gain. ${ }^{*} p<0.05,{ }^{* *} p<0.01,{ }^{* * *} p<$ 0.001 .

Table 2. Urinary excretion of C-peptide (mean $\pm S D$ ) during $8 \mathrm{~h}$ after meal in different feeding groups at 6 mo

\begin{tabular}{|c|c|c|c|c|}
\hline & & U-C-peptide & U-C-peptide & \\
\hline Group & $\begin{array}{c}\text { U-C-peptide } \\
(\mathrm{nmol} / \mathbf{L})\end{array}$ & $\begin{array}{l}\text { U-Creatinine } \\
\text { (nmol/ } \\
\text { mmol) }\end{array}$ & $\begin{array}{c}\text { Body surface } \\
\text { area } \\
\left(\mathrm{nmol} / \mathrm{m}^{2}\right)\end{array}$ & $n$ \\
\hline $\mathrm{BF}$ & $2.2 \pm 2.1$ & $1.7 \pm 1.4$ & $6.3 \pm 6.0$ & (10) \\
\hline F 1.3 & $2.9 \pm 1.9$ & $2.6 \pm 1.5$ & $7.9 \pm 5.1$ & (9) \\
\hline F 1.8 & $7.0 \pm 4.8^{*} \dagger$ & $4.4 \pm 2.1 \dagger \ddagger$ & $19.4 \pm 12.9^{*} \dagger$ & (9) \\
\hline
\end{tabular}

$* p<0.05$ when BF-group was compared to $\mathrm{F} 1.8$

$\dagger p<0.05$ when F 1.3 -group was compared to F 1.8 Student's $t$-test. $\ddagger p<0.01$ when BF-group was compared to F 1.8 . 